ces is not merely inappropriate but absurd: the world knows that there are often empty quarrels over priority in science, but Steele is picking a quarrel over priority for an idea which, in most people's judgement, is literally unproven (and which may be wrong). That will not do much good for the public reputation of science.

\section{Monopolies die hard}

\section{British Telecom, a nationalized industry now private, seems still to hanker after old ways.}

WHEN the British government decided, five years ago, to get out of the telecommunications business, one of the most powerful arguments in its favour was the calculation that a private business would perforce respond more quickly to its customers' needs than would a quasi-business run by quasi-businessmen employed as civil servants. On balance, the argument has been shown by experience to have been correct. People wanting access to telephones no longer have to wait for months or years, but only weeks or sometimes even days. Moreover, the costs of using telephones have not risen nearly as quickly as had been expected by those who remarked that the privatized nationalized industry would still retain a virtual monopoly of telephone traffic. Tariffs have been controlled by regulation, private British Telecom has made more economical use of capital than its public predecessor of the same name, telephone users have likewise been able to make the best use of their capital by choosing whether to buy or lease equipment, the volume of business has (predictably) grown more quickly than expected and, in any case, such rapacious instincts as British Telecom may have have been constrained by the generally lower tariffs offered by Mercury, its sole licensed competitor. On the face of things, privatization seems to have worked, at least in the telecommunications business. Customer power has won through.

But has it? Towards the end of last year, British Telecom published the first issue of a glossy magazine called Telecom, subtitled British Telecom World, with a cover price like that of Nature and stuffed with advertisements from British Telecom suppliers. Proudly, the new magazine promised to avoid being either a "gadget book" or an "equally indigestible" account of international telecommunications policy. Instead, it offered to harness British Telecom's "fund of expert knowledge and credibility" to the provision of a magazine that would be neither "a glorified brochure" nor a "marketing hand-out".

Sadly, more detailed inspection of the words gives the game away. In the old days, when British Telecom's predecessor was a government department, some British telephone users knowledgeable about practice elsewhere were used to plead that they should be given with their bills an explanation of how the imputed charges had arisen - "itemized billing" seemed to have become a customer need even while customers were still captive clients. While a public monopoly, British Telecom became skilled at dismissing these demands in a host of different ways. In the new climate in which customer demands, however whimsical, must be acknowledged to have some objective reality, the privatized company seems instead to take the view that users' yearning to know the basis on which their bills are calculated is a delusion which, if satisfied, is as likely to bring tears as a child's willingness to surrender innocence for a knowledge of grown-up life.

Thus one page of the new glossy, adorned by a tantalizing (to British users) vision of what may be an itemized telephone bill, makes two simple points. First, having planned that there should be itemized billing for all by 1995 , British Telecom is now cobbling together ways of doing the job more quickly; half of Britain's telephone users should enjoy the privilege by 1990 . (Oddly, the article neglects to mention that Mercury Communications offers itemized billing to all its customers already.) Second, which is where the old nanny comes in, crusading
Telecom disinters the old excuse that the provision of the right to know how a telephone bill is calculated "would distract valuable engineering resources" from the task of modernizing Britain's telephone system. Much in the spirit of ". . . they know not what they do", Telecom remarks that large users are not equipped to handle bulky bills, while some spouses would wish guiltily to conceal their telephone usage from their partners.

The sad moral in this gloomy tale is that privatization by itself does not change public monopolies into private companies, but that time is also necessary if an organization's facetious scorn for the private persons who provide its revenue is to melt away. Mercifully, for the customers, British Telecom has a geographically omnipresent competitor. The British government, which is this year planning to privatize both the nationalized electricity and water industries, should even at this late stage give some thought to the circumstance that monopolistic complacency will there be more easily sustained.

\section{Hope before reality}

\section{The British government's latest view of higher} education hangs on assumptions still unproven.

BRITISH academics should not let their emotions get the better of their judgement when reading reports of Mr Kenneth Baker's speech at Lancaster last week (see page 105). After a decade of enforced contraction of the British university system, it is bound to seem mystifying that the Secretary of State for Education and Science should be talking of a quite different world in which the proportion of young people in higher education has doubled. People are bound to ask what perversity can explain why the university system should first contract so that it can grow to a size sufficient to meet modern needs. Before they accuse Baker of inconsistency, or worse, they should allow that he was talking last week of a university system quite different from that to which his predecessors took an axe in 1980. The question is not whether Baker is being inconsistent but whether the system of which he now speaks is more substantial than a mirage.

The objective, or hope, is that there will emerge from present academic institutions a system of higher education that is more diverse than at present, thus catering more adequately for the demands of the supposed market in higher education, but whose growth (at least) will be sustained by other than public sources of funds. Baker apparently has in mind the fees paid by eager students and the contributions that successful industries will be impelled to make in academic institutions which are essential to their own well-being. Baker likened his vision of British higher education to that of higher education now in the United States. British academics and universities might even embrace that vision if they believed that it would come true. The truth, as always, is more complicated. Even the analogy with the United States is misleading. The University of California system, comparable in size with the British university system and qualitatively enviable, is supported by the state of California.

Many other state systems are almost in the same league. Moreover, while many of the private universities in the United States are outstanding (and outstandingly successful) academic institutions, they enjoy the benefit of large endowments accumulated over a century of prosperity - not to mention the continuing generosity of their alumni. Yet experience in the United States has shown that industry is not the endless source of funds that it might be, even with much more generous tax incentives than the British government has put in place. Nor does it make sense that higher education, which is in the best sense subversive of present contentments, should become overdependent on self-interested industry. Baker's hope that British higher education can prosper in an entirely free market turns on the assumption that Britain is certain to reach that prosperous condition his financial colleagues in the government are fond of talking of, but that puts the cart before the horse. 